\title{
Безопасность в коммуникационном обществе: возможности и вызовы
}

\author{
Величка Милина *
}

Информация часто является ключевым ресурсом мощи, и больше, чем когда-либо людей имеют больший, чем когда-либо доступ к информации ... В этом мире сети и связанность становятся важным источником соответственной мощи. ${ }^{1}$

Джозеф С. Най, Младший

Мощь всегда зависит от контекста. 2011 год сделал констатацию Джозефа Ная четко видимой для всех акторов в сфере политики безопасности. Волнения в странах «Арабской весны» (еще продолжающиеся в Сирии) и протесты, которые вспыхнули в разных странах по всему миру в результате неэффективной правительственной политики в отношении глобального финансового и экономического кризиса, категорически доказали, что политическую стабильность (безопасность) нельзя рассматривать и нельзя достичь только в контексте традиционных институтов и норм представительной демократии, или путем вселения страхов и внушения убеждений в закрытом обществе. Эти события продемонстрировали появление новых форм и масштабов политической активности и потребовали компетентное политическое участие. Несмотря на их обширную географию, их объединяет то, что все они были организованы и проведены с помощью новых коммуникационных технологий.

Сегодняшним контекстом политики безопасности является коммуникационное общество. Феномен, который попадает под рубрику «Web 2.0», радикально изменил как характеристики объектов безопасности (отдельных личностей, общества, государства), так и проблемы, с которыми сталкивается безопасность - начиная с Твиттер-революций, через протесты «недовольных» и достигая кульминации в ключевой роли социальных средств массовой информации как инструментов «мягкой силы». Эта статья является попыткой оценить и проанализировать параметры этих изменений в качестве вызовов и новых возможностей для систем безопасности в коммуникационном обществе.

\section{Коммуникационное общество}

До недавнего времени мы привыкли определять мир, в котором мы живем, как «информационное общество». Но если мы тщательно проанализируем тенденции

\footnotetext{
Кандидат политических наук Величка Милина является доцентом в Национальной военной академии им. Г.С. Раковского в Софии, Болгария.

Joseph S. Nye, Jr., The Future of Power (New York: PublicAffairs, 2011), 116, xvi.

2 Там же, xiv-xviii.
} 
истекшего десятилетия, мы можем доказать, что это утверждение уже не отражает в достаточной степени специфику настоящего времени. Хотя и количество доступной информации непрерывно увеличивается, сегодня будет более удачно сказать, что мы являемся свидетелями революции, предоставляющей нам новые альтернативные инструменты коммуникации. Эти коммуникационные технологии сосредотачиваются не на увеличении объема доступной информации, а на развитии разнообразных инновационных и эффективных форм массовой коммуникации из центральных точек к большому числу людей, а так же на создании новых способов обмена информацией между индивидуальными акторами. Феномен «коммуникации» движется к приобретению статуса основного объяснительного принципа во многих общественных науках.

Эволюция Интернета в начале двадцать первого века включала развитие разнообразия технологий, которые в своем сочетании стали известны как Web 2.0 (Сеть 2.0). Этот этап в эволюции Интернета характеризуется появлением социальных сетей, социальных средств массовой информации и генерированного потребителями содержания - предоставлением индивидуальным пользователям статуса креативного фактора, а не просто традиционного потребителя выпусков средств массовой информации. Жизненно важной чертой этого периода является использование Интернета не только в качестве «коммуникационной среды», но и «платформы». ${ }^{3}$ Такие платформы могут создаваться и усовершенствоваться как профессиональными дизайнерами, так и индивидуальными пользователями. Одним из самых важных результатов Сети 2.0 является создание социальных («новых») медиа как новых средств массовой онлайн-информации, где каждый пользователь Интернета-даже тот, у которого нет специальных знаний программиста-может принимать участие в создании, сохранении и распространении социально значимой информации, адресованной широкой публике. ${ }^{4}$

Широкое распространение этих «новых медиа» превратило их в просто «медиа» для большого числа людей. Традиционными медиа (средствами массовой информации) считаются: печатные материалы (газеты, журналы и т.п.), радио, телевидение, кино- и видеопрограммы и цифровые (электронные) издания (так называемая Сеть 1.0) газет, информаций и выпусков новостей. Хотя никакой официальной «научной» дефиниции пока не существует, понятие «новые медиа» используется для обозначения Интернет-базированных (формат Web 2.0) цифровых, компьютеризированных, сетевых информационных и коммуникационных техно-

3 Tim O'Reilly, "What Is Web 2.0: Design Patterns and Business Models for the Next Generation of Software" (30 September 2005); доступно на: http://oreilly.com/web2/archive/what-isweb-20.html.

4 Смотри: М.С. Будолак, Понятие «социальные медиа», в Петербургская школа PR: om теории к практике, Вып. 7, Отв. ред. А.Д. Кривоносов (Санкт-Петербург: Роза мира, 2009), c. 18. 
логий, таких как блоги, вики-сайты, ${ }^{5}$ социальные сети, сайты для совместного использования файлов и т.д.

Всего за несколько лет социальные медиа изменили мир, в котором мы живем. В результате, в обращение вошли такие неологизмы, как «электронное государство 2.0», ${ }^{6}$ «демократия 2.0», ${ }^{7}$ «революция 2.0», ${ }^{8}$ «публичная дипломатия 2.0», «гражданское общество 2.0», ${ }^{10}$ и «политика $2.0 »{ }^{11}$

\section{Коммуникационные технологии и безопасность}

Каким образом революция в области коммуникаций изменила среду безопасности и какими являются новые вызовы и возможности для систем безопасности в контексте политической стабильности общества? Основным соображением при ответе на этот вопрос является тот факт, что коммуникационные технологии Сеть 2.0 радикальным образом изменили традиционные способы создания и распространения информации. Принято считать, что политическая коммуникация охватывает ряд процессов, включающих обмен информацией и передачу политической информации, которые формируют политические действия и придают им новый смысл. В информационной эпохе цифровые медиа становятся главным-и для растущего числа людей единственным-каналом политической информации и коммуникации. Они являются основным пространством для политической активности, где граждане получают политическую информацию, формируют свои политические взгляды и убеждения и располагают возможностью влиять на процессы, связанные с функционированием власти. Согласно Лусиану Паю, политическая коммуникация не состоит из односторонне-направленных сигналов от

5 Вики - гавайское слово, которое означает «быстрый». Вики-медиа подразумевает, что содержание данного сайта быстро может быть модифицировано потребителями при использовании какого-нибудь простого веб-браузера.

6 Soon Ae Chun, Stuart Shulman, Rodrigo Sandoval, and Eduard Hovy, "Government 2.0: Making Connections Between Citizens, Data and Government," Information Polity 15:(1\&2) (2010): 1-9.

7 Anand Giridharadas, "Democracy 2.0 Awaits an Upgrade," New York Times (11 September 2009); доступно на: www.nytimes.com/2009/09/12/world/americas/12iht-currents.html? $\mathrm{r}=1$ \&pagewanted=all.

8 Wael Ghonim, Revolution 2.0: The Power of the People Is Greater than the People in Power: A Memoir (Boston: Houghton Mifflin Harcourt, 2012).

9 Lina Khatib, William H. Dutton, and Michael Thelwall, "Public Diplomacy 2.0: An Exploratory Case Study of the U.S. Digital Outreach Team," The Middle East Journal (2012); доступно на: http://papers.ssrn.com/sol3/papers.cfm?abstract_id=1734850.

10 Смотри: www.state.gov/r/pa/prs/ps/2009/nov/131234.htm.

11 Orlin Spassov, "Social Networks and Politics 2.0," доступно на: http://www.seminar-bg.eu/ spisanie-seminar-bg/broy1/item/198-\%D1\%81\%D0\%BE\%D1\%86\%D0\%B8\%D0\%B0\%D0\% BB\%D0\%BD\%D0\%B8-\%D0\%BC\%D1\%80\%D0\%B5\%D0\%B6\%D0\%B8-\%D0\%B8-\%D0 \%BF\%D0\%BE\%D0\%BB\%D0\%B8\%D1\%82\%D0\%B8\%D0\%BA\%D0\%B0-20.html. 
элиты к массам, а включает целый спектр неформальных коммуникационных процессов в обществе, которые имеют разнообразное влияние на политику. ${ }^{12}$

Бесспорным является факт, что за прошедшие несколько лет Интернет стал местом, где заявляются политические позиции, проводятся диспуты и дискуссии, образуются общества по определенным политическим поводам или вокруг долгосрочных политических идей, получают политическую информацию и на последнем (но не по значению) месте, общество коммуникирует с теми, кто находится у власти. Наиболее подходящими среди реализаций «новых медиа» для целей настоящего анализа - это блоги и социальные сети.

\section{Оборот информачии в природе «новых медиа»}

В среде, которую называют «новая медиа», информация создается и распространяется способом, совершенно отличным от способа, что являлся характерным для коммуникации на протяжении большей части двадцатого века. В традиционных средствах массовой информации, даже в системах с обратной связью, информационный инструмент есть источник информации и он играет ведущую роль в процессе коммуникации. Другими словами, мир традиционных медиа есть мир односторонней коммуникации, в котором информация сначала фильтруется, а затем распространяется. С «новыми медиа» публика создает и распространяет информацию онлайн; только после этого ее можно отфильтровать или заблокировать. Это обстоятельство коренным образом меняет ответ на жизненно важный для каждой системы безопасности вопрос: «Кому принадлежит, кто контролирует и кто распространяет информацию»?

«Новая медиа» радикально изменила скорость с которой циркулирует политическая информация. Нет сомнения, что онлайн-информация о политических событиях и процессах далеко обошла информацию, поставляемую традиционными средствами массовой информации в смысле актуальности и динамики обновления. Дополнительно «новые медиа» так же дают возможность пользователям поделиться различными точками зрения на одно и то же событие, практически одновременно с его развитием. Все чаще и чаще это точки зрения очевидцев, распространенные через Твиттер или какой-нибудь блог. Существует много таких примеров, начиная от самоубийственного взрыва в московском аэропорту в январе 2011 года и кончая событиями Арабской весны.

Социальные медиа меняют наше восприятие того, как мы общаемся с остальным миром. Этот тип коммуникации стал исключительно демократичным. Не нужно быть опытным IT профессионалом или быть богатым, чтобы общаться с большим числом людей, разбросанных по всему миру. Каждый, у кого есть доступ к компьютеру, подключенному к Интернету, может создать блог или социальную сеть, написать на вики-сайте, сделать пост-, аудио- или видеозаписи - и после этого может получить тысячи комментариев, и в принципе, стать влиятельной

12 Lucian Pye, "Political Communication," в The Blackwell Encyclopedia of Political Institutions, под ред. Vernon Bodganor (Oxford: Wiley-Blackwell, 1987). 
личностью, которая может формировать мнение и отношение к различным политическим, общественным или культурным событиям и вопросам. Как говорят политические консультанты, в новых медиа информация идет «от двери к двери», или точнее - «от акаунта к акаунту». Это сеть, которая создается от человека к человеку, от группы к группе, и она не может быть перекрыта по вертикали никоим образом. Это и есть причина, по которой системы, основанные на вертикальном распределении коммуникационных сигналов (в направлении к гражданам и идущие от граждан), сегодня уже не эффективны. Чтобы механизмы политического влияния стали эффективными, необходимо их изменить, используя новые средства коммуникации.

Новые медиа усугубили и сделали видимым кризис в традиционных массовых политических коммуникациях. Само представление о «массах» приобрело другое значение. В контексте подхода традиционных медиа, «массы» воспринимаются как некое аморфное тело, не имеющее структуру и с расплывчатым составом. Если, однако, мы посмотрим на современное Интернет-сообщество, мы увидим, что несмотря на то, что оно состоит из сотен миллионов людей, его нельзя назвать «массой». Интернет-сообщество имеет четкую горизонтальную структуру. Функционирование многочисленных онлайн-сообществ сформировало группы пользователей, которые в большинстве случаев могут быть четко дифференцированы в соответствии с их социальными, демографическими, религиозными или другими характеристиками, но тем не менее связаны вместе виртуальной связью, созданной онлайн-сообществами. Это превращает Интернет-сообщество в особый феномен, совершенно отличный от аморфной массы и от моделей, используемых в классических теориях политической коммуникации.

В дополнение, в среде новых коммуникаций уже невозможно пренебрегать наличием точки зрения меньшинства. Причина в том, что благодаря революции в коммуникациях, по словам Маршалла МакЛухана, «слишком много людей знает слишком много друг о друге ...». ${ }^{13}$ Это совершенно новое обстоятельство изменит представление о том, как происходит массовая коммуникация.

Позитивный потенциал новых социальных средств массовой информации состоит в том, что они предоставляют правительствам эффективный инструмент для прямой коммуникации более органичным и соответствующим местным реалиям способом. Социальные сети дают политикам очень четкий и точный профиль общества в параметрах географии, возраста, занятия, доходов и интересов. Уже стало привычным сравнивать социальные сети с GPS системой в контексте социальной географии. Это очень мощный инструмент для эффективной и выгодной политической коммуникации.

Новым в политической коммуникации является то, что средний гражданин уже не «почтовый ящик» для политической информации, пассивно получающий послания, распределяемые из центра. Отдельный человек уже располагает возмож-

13 Marshall McLuhan, Quentin Fiore, and Jerome Agel, The Medium is the Massage: An Inventory of Effects (New York: Bantam Books, 1967). 
ностью непосредственно выразить и распространить свое мнение или отношение по определенному вопросу в качестве участника форума или в социальной сети путем голосования, «лайк»-ая или «дислайк»-ая, записывая и делая посты клипов и т.п. Чем больше число таких действий вокруг определенного события, тем быстрее движется информация и тем шире спектр аудитории. В эволюционной фазе Интернета, обозначаемой как Сеть 1.0, такое движение информации не могло происходить со сравнимой скоростью и в сравнимом масштабе, несмотря на наличие чат-румов, электронной почты и мгновенного обмена сообщениями.

Тенденция к использованию социальных медиа для дистрибуции политической информации будет усиливаться для нового поколения пользователей, для которого новые медиа являются естественным местом для получения информации, таким, каким телевидение было для предыдущего поколения. Эффективными лидерами такого типа коммуникации будут те, кто «думает о себе как о находящимися в круге, а не на вершине горы» ${ }^{14}$ и те, кто понимает, что «двусторонняя связь эффективнее команд». ${ }^{15}$

\section{Новые медиа и новая социальная реальность}

Социальные медиа сделали коммуникации присущими всем областям современного мира. Основная ценность таких медиа для современного человека состоит в возможности получать, перерабатывать, создавать и передавать информацию, в результате чего сегодня люди живут не столько в окружении людей, а в мире, полном изображений, сообщений, мифов и стереотипов. Политическая коммуникация тоже характеризуется преобладающе символическим характером. Она реализуется миллионами знаков, символов и образов, формирующих отдельный тип реальности, которая субъективно воспринимается участниками коммуникационной сети как единственно существующей.

Для отдельного человека эта символьная среда уже не является посредником между ним и реальным миром, где случаются события и существуют явления, а скорее является заместителем реального мира. Новая реальность все более удаляется от существующих реальных (преимущественно политических) отношений, и в то же время оказывает на них нарастающее влияние.

Эту парадоксальную взаимосвязь можно объяснить так называемой «теоремой Томаса», которая гласит, что «если люди определяют ситуации как реальные, они и становятся реальными в своих последствиях». Сейчас мы являемся свидетелями ренессанса «теоремы Томаса» (впервые сформулированной в 1928 году) благодаря одному из наиболее влиятельных социологов последних пятидесяти лет, Роберту Мертону, известному своими работами по прогнозированию автодеструктивного поведения. ${ }^{16}$ В своих исследованиях он анализировал влияние правила, сформули-

14 Nye, The Future of Power, 101.

15 Там же.

16 Robert Merton, “The Thomas Theorem and the Matthew Effect?," Social Forces 74:2 (1995): 380; доступно на: http://garfield.library.upenn.edu/merton/thomastheorem.pdf. 
рованного Томасом: когда люди верят во что-нибудь, они действуют в соответствии со своими убеждениями - какими бы не были их действия, конструктивными или деструктивными.

Сегодня новая реальность символических образов и изображений безусловно доминирует в политической жизни. Политика в коммуникационном обществе «может быть, в конечном счете тем, что утверждается в той истории, которой поверят». ${ }^{17}$ В этом смысле основным вопросом является: что такое правда в двадцать первом веке? ${ }^{18}$ Традиционно политическая правда преподносится экспертами на основе реальных практик, эмпирических фактов, науки и знаний. Сегодня, когда даже меритократическая элита в упадке, власть больше не легитимируется компетентностью. Появилось новое понимание об истине, характеризуемое представлением, больше не существует традиций и не существуют эксперты. Истина удаляется от компетентности. Мнение блоггера-любителя может быть «лайкнуто» большее количество раз, чем мнение университетского профессора. Тот, кто рассказывает более интересную историю, вызывает больше доверия.

Эта новая реальность поднимает ряд вопросов, на которые пока нет ответов. Эти вопросы связаны с сущностью политики как средства рационализации конфликтов и с ответственностью политических лидеров за обеспечение стабильности в их обществе.

\section{Новые медиа и оркестровка событий в реальном мире}

Выражение «революции в социальных сетях» сегодня обобщает представления о новых формах политической активности. Средства массовой информации и эксперты определили события, которые имели место в 2011 году в Тунисе и в Египте-так называемая «Арабская весна»,-как «Твиттер революции» или «Фейсбук революции», потому, что именно через эти социальные сети произошла мобилизация и организация активных участников этих событий. В этих случаях альтернатива официальным средствам массовой информации стала широко популярной и впервые распространялась информация о том, что происходит на земле, а не только в эфире. Иначе говоря, социальные медиа исполняли информационную, организационную и мобилизационную роли в волнениях во время «арабской весны». Можем ли мы в результате этого согласиться с утверждением советника

17 John Arquila and David Ronfeldt, The Emergence of Noopolitik: Toward an American Information Strategy (Santa Monica, CA: RAND, 1999), іх-х; доступно на: www.rand.org/pubs/ monograph_reports/MR1033.html. Цитировано в Nye, The Future of Power, 104.

18 Peter Faber, "Power and the Westphalian System: Goodbye to All That," International Relations and Security Network Podcast, 2 April 2012; доступно на: www.isn.ethz.ch/isn/CurrentAffairs/Podcasts/Detail/?ots591=40db1b50-7439-887d-706e-8ec00590bdb9\&lng=en\&id= 138980. 
Хилари Клинтон по инновациям, Алека Росса, что социальные медиа - «это новый Че Гевара двадцать первого века»? ${ }^{19}$

В сущности, волнения в Белоруссии (2006), в Молдове (2009), в Иране (2009), «арабская весна» (2011), массовые движения протеста против неэффективной бюджетной политики в ряде западных странах (2011) и в России (2011) являются иллюстрациями потенциала широкомасштабной, высокоинтенсивной политической мобилизации через социальные медиа. Поклонники «Твиттер революции» убеждены, что причиной относительного успеха этих движений является сама технология. Протестующие имеют возможность координировать свои действия через социальные сети; сообщение в Твиттере или в Фейсбуке дает людям чувство причастности, а посты фотографий или видеоклипов обеспечивают эффект присутствия. В результате о событиях становится известно миллионам людей по всему миру, они могут принимать участие в кампаниях «указать и устыдить» (naming and shaming) и формировать глобальное общественное мнение в поддержку определенной идеи, настаивая на активный ответ со стороны своих правительств. Глобальные Интернет-серверы позволяют революционному духу быстро переходить из одной страны в другую. Можно себе представить, что если революция и не будет показана по телевидению, она будет транслироваться в Твиттере.

\section{Ограничения освободительной роли новых медиа}

Эта роль социальных медиа, однако, сильно преувеличена и воспринимается однобоко. Согласно Евгению Морозову из Станфордского университета, который был первым ученым, введшим термин «Твиттер-революция» после событий в Молдове в 2009 году, революции не происходят из-за того, что существуют определенные технологии. В их основе лежат политические, экономические и общественные факторы. Это утверждение доказывается фактом, что несмотря на некоторые ожидания того, что социальные медиа сыграют ту же прогрессивную роль в Китае и в России, этого не произошло. По Морозову, единственным возможным объяснением является то, что правительства тоже оказываются в состоянии успешно работать с новыми технологиями. В Китае, России, Иране и Судане власти активно используют социальные медиа, чтобы идентифицировать и нейтрализовать организации оппозиционных активистов. ${ }^{20}$ Технологии нейтральны; это просто средства и инструменты, и успех, проистекающий из их применения, определяется конкретными фактами: социологической осведомленностью, наличием действительных социальных и политических противоречий, существованием оппозиционных настроений в данном обществе. Этими процессами легко манипулировать, усиливать или ослаблять их через социальные медиа, но в любом случае

19 Alec Ross and Ben Scott, "Social Media: Cause, Effect, and Response," NATO Review (2011); доступно на: http://www.nato.int/docu/review/2011/Social_Medias/21st-century-statecraft/en/ index.htm.

20 Евгений Морозов, «Цена вопроса», Коммерсантъ 39/С (4580), 09.03.2011; доступно на www.kommersant.ru/doc/1595762/print. 
должна присутствовать реальная политическая активность. Очень часто расстояние между нажатием «лайк»-а в социальной сети или блоге и подлинным участием оказывается непреодолимым, особенно в контексте пассивной политической культуры.

«Новый Че Гевара» Твиттер-революций оказывается бессильным в периоде после того, как достигнута начальная политическая победа, когда нужны организация и импульс для следующей фазы строительства. Отсутствие политической идеологии, программы или организации-так же как и опасение, что некоторые лидеры узурпируют «победу» или используют политический результат для личной выгоды,-могут привести к хаосу и неопределенности.

Сегодня трудно доказать, что все эти массовые политические события-начиная с Туниса и кончая Россией-произошли бы, если бы не существовало Сети 2.0. Однако ясно, что они не произошли бы таким образом, в таком масштабе и с таким разнообразием участвующих.

Участниками этих событий были так называемые «умные толпы». Этот термин был введен Хауардом Рейнгольдом и он кажется оксимороном, если воспринимать толпу в контексте докоммуникационной эры, когда это слово было синонимом иррационального и инстинктивного поведения. ${ }^{21}$ «Умная толпа» состоит из отдельных людей, которые общаются посредством беспроволочной связи и для которых мобильная коммуникация превратилась в разновидность «электронного протеза, отсутствие которого угрожает их персональной идентичности». ${ }^{22} \mathrm{~B}$ наши дни это понятие применяется к «каждому быстро формирующемуся и демонстрирующему коллективный интеллект сообществу в Интернете». ${ }^{23}$

По мнению некоторых аналитиков похоже, что «умные толпы» или станут ключевым ресурсом для формирования гражданского общества, или превратятся в деструктивную силу. Сегодня, после событий 2011 года, мы возвращаемся к идее Рейнгольда относительно нового способа вовлечь людей в эпоху коммуникаций в групповые или коллективные виды деятельности - он называет их «ад-хокрациями» (от латинского выражения ad hoc, означающее «для определенных целей»). ${ }^{24}$ Это социальное сообщество нового типа, появившееся в результате конвергенции мобильных коммуникаций и компьютеров, в котором у людей есть возможность сходиться на время, чтобы поделиться информацией, общими интересами и деятельностями. В «адхокрации» нет никакой иерархии, нет легитимного лидера и нет четкого разделения труда. ${ }^{25}$ Эти характеристики наблюдались в протестных движениях, где мобилизация участников и организация проводились через социальные медиа. Пока адхокрация не показывает особенно обещающие результаты.

21 Howard Rheingold, Smart Mobs: The Next Social Revolution (New York: Basic Books, 2002).

22 Виктор Буряк, Глобальное гражданское общество и сетевые револющии (Симферополь, 2011), 90; доступно на: www.bazaluk.com/book/files/211.pdf.

23 Христо Проданов, Цифрова политика (София, 2011), 170.

24 Rheingold, Smart Mobs, 80-82.

25 Смотри: Проданов, Цифрова политика, 168-74. 


\section{Усовершенствованные коммуникации и изменения в современной демократии}

До сих пор большая часть политических деятельностей, тех, что инициировались с использованием новых коммуникаций и новых медиа, были оппозиционными по своей ориентации и таким образом порождали неопределенность и политическую нестабильность. В 2011 году мы стали свидетелями массовых протестных движений против бесплодных попыток политиков преодолеть экономический кризис в ряде либеральных демократических государствах, - начиная с Испании и продолжая Бельгией и Германией, Соединенными Штатами и Австралией. Общим между всеми этими движениями было то, что протесты были организованы через социальные сети и были весьма широкомасштабными. Кульминация была достигнута 15 октября 2011 года, когда глобальное движение недовольных использовало социальные сети, чтобы призвать к протестам в более чем 700 городах, в более чем 70 странах с сотнями тысяч участников. ${ }^{26}$

Эта новая модель политического участия, основанная на социальных сетях, провоцировала журнал Foreign Affairs опубликовать комплексный анализ вопроса, как новые социальные движения меняют классический политический процесс, написанный учеными-политологами Майклом Хардтом и Антонио Негри. ${ }^{27}$ По мнению этих исследователей, наиболее неожиданным открытием стало то, что случающееся во время протестов имеет мало общего с дебатами, происходящими между политиками. Эти две вещи существуют как бы в параллельных реальностях, что поднимает вопрос, способны ли политические системы современной демократии выражать и представлять интересы и жизненно важные требования множества избирателей.

В сущности, протестные движения, которые потрясли либеральные демократии («Займи Уолл-Стрит», «Займи Вашингтон», «Займи Лондон», «Движение недовольных» и т.д.), так же как и правое поппулисткое движение «Чаепитие» в США, поднимают вопрос об эффективности сегодняшней политической модели. До недавнего времени безопасность и политическая стабильность в консолидированных демократиях выглядели безусловными. Современная представительская демократия существует более чем двести лет. Граждане периодически выбирают своих представителей, и если они недовольны ими, они их заменяют во время очередного голосования через несколько лет. Однако в эпоху Интернета, социальных сетей и Викиликс, делегирование своего голоса выбранному представителю и поиск альтернатив в конце представительского срока выглядит все более неуклюжим и неэффективным. Когда протестующие собираются на улицах Манхэттена и

26 Смотри: http://bnt.bg/bg/news/view/62253/protestite na nedovolnite.

27 Michael Hardt and Antonio Negri, "The Fight for 'Real Democracy' at the Heart of Occupy Wall Street: The Encampment in Lower Manhattan Speaks to a Failure of Representation," Foreign Affairs (11 October 2011); доступно на: www.foreignaffairs.com/articles/136399/ michael-hardt-and-antonio-negri/the-fight-for-real-democracy-at-the-heart-of-occupy-wallstreet. 
кричат «Так выглядит демократия», они настаивают на прямом участии людей в политическом процессе. ${ }^{28}$

Постмодерная эпоха обозначила кризис политического представительства как основной фактор общественной нестабильности в демократических государствах. В новой атомизированной социальной структуре сверх-символьных экономических обществах люди группируются во множество динамических меньшинств и часто не видят в политических партиях, отражающих статус-кво прошедшей индустриальной эпохи, представителей своих интересов. ${ }^{29} \mathrm{C}$ одной стороны, это приводит к увеличению политической коррупции и политического популизма, а с другой стороны - к политическому недоверию и массовому отказу граждан участвовать в политике.

Не далее как в 1994 году Элвин и Хейди Тоффлер в книге «Создание Новой цุивилизации» комментировали параметры демократии в двадцать первом веке и говорили о необходимости изменения отношений между правительством и «неустойчивыми и множащимися меньшинствами», которые стали динамически появляться после падения централизованно-плановых обществ коммунистического Востока. ${ }^{30}$ По их мнению, демократия, основанная на принципе правления большинства, становится неэффективной в информационной эпохе и должна быть заменена «демократией меньшинств» с помощью «методов, чья цель обнажать трудности, а не прикрывать их, декларируя мнение вынужденного или фальшивого большинства, достигнутого исключением некоторых групп из голосования, усложнением формулировки проблемы или дискредитацией выборных процедур». Вместо того, чтобы сосредотачивать усилия на формировании коалиции из групп для обеспечения большинства, Тоффлеры указали, что «роль различных меньшинств должна увеличиваться с тем, чтобы они переросли в большинство». ${ }^{31}$

На фоне массовых протестов по всему земному шару в 2011 году, которые сделали явным кризис официальной демократии, аргументы этих двух футуроло-

28 Смотри: www.capital.bg/politika_i_ikonomika/sviat/2011/10/14/1177444_ulica_protestna.

29 Это подтверждается быстрым ростом популярности и успеха так называемых пиратских партий. Начиная с первой, созданной в Швеции в 2006 году, сейчас пиратские партии существуют в более чем двадцати демократических странах. Они участвуют в Интернационале Пиратских Партий (ИПП), который примет участие в выборах в Европейский парламент в 2014 году, где у них уже есть два члена из Швеции. Пиратская Партия Германии получила 12 процентов голосов на последних выборах, и у нее есть представители в парламентах в Берлине и Саарланде. Ключевыми для пиратских партий являются вопросы прозрачности, процедуры открытого государства и лучшая коммуникация с гражданами. Смотри: “Germany's Pirate Party: The Ayes Have It,” The Economist (28 April 2012); доступно на www.economist.com/node/21553484. Смотри так же: Sarah Marsh and Hans-Edzard Busemann, "Pirates Party's Rapid Rise Upsets German Landscape," Reuters.com (30 April 2012); доступно на: http://www.reuters.com/article/2012/04/30/us-germany-piratesidUSBRE83T08G20120430.

30 Alvin and Heidi Toffler, Creating a New Civilization: The Politics of the Third Wave (Sofia, 1995), 108-09.

31 Там же, 109. 
гов, похоже, оправдываются. Они пришли к заключению, что для того, чтобы демократическая политическая система была эффективной в новой эпохе, ей нужно пройти через переходный период от представительской к «полупрямой демократии», что означает перейти от «зависимости от представителей к самопредставительству». ${ }^{32}$ Полупрямая демократия является формулой, которая не противопоставляет, а включает использование процедур прямой и представительской демократии.

До сих пор два основных препятствия задерживали реализацию идеи расширенного использования механизмов прямой демократии в политическом управлении: технические проблемы участия и проблема компетентности. Основанные на Сети 2.0 технологии коммуникационного века предлагают решение обеих проблем. Социальные медиа представляют собой техническое решение проблемы массового политического участия, предоставляя платформу для озвучивания мнений и для генерирования сообществ вокруг определенной заявленной позиции. Новые медиа позволяют гражданам не только сказать «да» или «нет» по определенной проблеме управления, но и приводить аргументацию по вопросу, предлагать решения и политику, формулировать проблемы и устанавливать повестку дня и приоритеты политического руководства.

Вторая, и более серьезная проблема, касающаяся компетентности при участии в политическом процессе, так же имеет новые измерения в коммуникационном обществе. Новые технологии сделали знание специфическим ресурсом власти, с несколькими важными характеристиками. Во-первых, знание является демократическим ресурсом потому, что для того, чтобы им владеть, человеку нужен только доступ к новым источникам информации. Во-вторых, знание является универсальным ресурсом потому, что его можно использовать для умножения других источников власти: богатства, репутации, организации. В-третьих, знание является неисчерпаемым ресурсом потому, что когда человек передает свои знания другому (и тот их усваивает), знание не уменьшается. Результат всего этого потенциально революционен: образованные люди, которые впервые в истории могут начать принимать свои собственные решения.

Действительно, пока еще нет четких моделей того, как может функционировать полупрямая демократия, какие процедуры и технологии будут наилучшим образом сочетать механизмы представительской и прямой демократии. Но решение этой проблемы определенно необходимо из-за несомненного бессилия традиционной представительской демократии генерировать безопасность и эффективно решать проблемы общественного развития в новом веке.

С точки зрения политической стабильности, большой потенциал новых социальных медиа-которые чаще всего упоминаются в контексте, негативных или оппозиционных кампаниях,- -лежит в технологических возможностях, которые позволяют конструктивное, творческое и массовое участие в политике. Одно из самых обещающих направлений, - это использование вики-сайтов. Вики - это

2 Там же, 111. 
среда, основанная на софте, который позволяет регулярным пользователям «создавать и редактировать свободно содержание веб-страниц, используя любой веббраузер». ${ }^{33}$ У вики-сайтов есть преимущество в том, что они осуществляют групповую коммуникацию, которая позволяет множеству людей принимать участие в создании, развитии и распространении содержания среди широкого круга читателей.

Есть примеры, показывающие полезные возможности вики-сайтов для облегчения публичного участия в разработке и обсуждении проектов программ политических партий, политики по определенным вопросам и законопроектов. Такие практики впервые были использованы неправительственными организациями; однако государственные институты (в России и в Новой Зеландии) тоже их применяли. ${ }^{34}$ Этот тип политических действий породил новые неологизмы, такие как «Законодательство 2.0» и «Экспертиза 2.0» Положительный эффект на политическую стабильность от таких методов участия в политике проявляется в усилении ощущения партнерства, которое они создают, и следовательно, в усилении лояльности и уважения к легитимности политики и законов. И это еще не все. Не меньшее значение имеют такие эффекты, как расширение круга экспертов, увеличение социального капитала, информирование о значимых социальных интересах и их балансирование, что означает большую стабильность и безопасность для общества.

Другой положительный эффект, оказывающий влияние на политическую стабильность демократий, создающих базированные на Сети 2.0 новые медиа, состоит в том, что эти медиа являются инструментом для сглаживания современных социальных конфликтов типа кратко описываемых словами «Мы против Них» или «1 \% против 99 \%». Это процесс двусторонний. С одной стороны, общество может использовать новые медиа, чтобы легче общаться с политиками, задавать им вопросы, выражать мнение или отношение к их работе. С другой стороны, политики становятся более «человечными» с помощью социальных медиа. Сегодня каждый современный политик имеет акаунт в социальных сетях и/или в блогосфере, и может использовать эти платформы, чтобы дойти до их участников и чтобы коммуникировать с ними напрямую относительно определенных решений или проблем. Без сомнения, политическая модель представительской демократии, такая, какой мы ее знаем, в скором времени подвергнется значительным изменениям, и эти изменения будут связаны с возможностями, основанными на Сети 2.0 новых медиа.

\section{Тот, кто контролирует Сеть 2.0, контролирует реальность}

Когда мы говорим о безопасности в контексте технологий Сеть 2.0, информационная безопасность представляет только малую толику обсуждаемых проблем.

33 "What Is Wiki," доступно на: www.wiki.org/wiki.cgi?WhatIsWiki.

34 "NZ Police Let Public Write Laws," BBC News (26 September 2007); доступно на: http://news.bbc.co.uk/2/hi/asia-pacific/7015024.sm. Относительно казуса России, смотри: www.brainity.ru/ society/trends/11051/. 
Мы говорим о радикально новом феномене: превращение социальных медиа в наиболее мощный инструмент мягкой силы. Прошло всего 8 лет со дня основания самой большой в мире социальной сети - Фейсбук. ${ }^{35}$ За этот короткий период на наших глазах новые социальные медиа стали наиболее эффективным инструментом для влияния на умы огромных сообществ, даже целых наций. Это объясняет, почему все аспекты колоссальной киберсферы-от блогов по конкретным вопросам до огромных социальных сетей, включающих сотни миллионов людей,- сейчас являются фокусом внимания правительств и корпораций, служб безопасности и террористических групп, политических партий и мозговых центров.

Технология Сеть 2.0 сама по себе нейтральна. Социальные медиа являются инструментом, который дает силу людям, желающим подтолкнуть свои правительства к поддержке определенных идей, ${ }^{36}$ что хотят скорректировать способ функционирования их правительств, или полностью изменить политический режим. Но новые медиа так же позволяют создание платформ, которые могут быть использованы против публичных интересов. ${ }^{37}$ Их можно использовать для распространения информации там, где она необходима, но так же распространять и дезинформацию. Сети предлагают новые возможности преступникам и террористам. Они могут быть использованы правительством для проведения операций под прикрытием.

В коммуникационном обществе «легитимность является реальностью власти». ${ }^{38}$ Слова становятся обменной монетой мягкой власти. Правительства соревнуются друг с другом и с другими организациями, чтобы укрепить свой кредит доверия и чтобы уменьшить кредит доверия своих оппонентов. ${ }^{39}$ Поэтому публичная дипломатия становится важным инструментом внешней политики для генерирования мягкой власти. «Публичная дипломатия» 2.0 основана на двустороннем диалоге, односторонняя коммуникация осталась в прошлом.

Соединенные Штаты располагают наиболее активной и наиболее успешной стратегией для использования новых медиа в публичной дипломатии. С 2009 года государственный секретарь США Хиллари Клинтон продвигает политику «цифро-

35 В апреле 2012 в Фейсбуке было зарегистрировано более 900 миллионов активных пользователей; смотри: www.facebook.com/ pages/Facebooking/114721225206500.

36 Тридцатиминутный любительский фильм “КОНИ 2012" Джейсона Рассела получил почти 90 миллионов просмотров до апреля 2012 года. Целью автора фильма было то, чтобы весь мир узнал об угандийском повстанческом лидере Джозефе Кони, которого обвиняют во множестве преступлений против человечества, - и которого следует арестовать до конца этого года. «Оружием» этой миссии стал Интернет и социальные сети. «Кони 2012» стало сообществом в социальных сетях, растущим быстрее всех. В конце последнего года США послали в Уганду 100 военных советников с целью арестовать Кони.

37 Уличные волнения в Англии в 2011 году, создание анти-иммигрантского вики-сайта в Нидерландах.

38 Nye, The Future of Power, 81.

39 Там же, 104. 
вой дипломатии» и «интернет свободы». ${ }^{40}$ Государственный департамент США потратил 28 миллионов долларов, чтобы расширить свои возможности для пропаганды, инноваций и в поддержку Интернет свободы в других странах мира. Послам и старшим дипломатам разрешено использовать Твиттер и Фейсбук для объяснения и защиты политики США за границей. В целом, Государственный департамент хостингует 288 Фейсбук страниц, 125 каналов Ютюба и твиттов на девяти разных языках, включая арабский, фарси, урду и китайский. Военный персонал США, в том числе и тот, который участвует в операциях за границей, получает «Руководство для работы с социальными медиа», что позволяет им (в определенных границах) так же участвовать в социальных сетях. Все это делает работу правительства США с социальными медиа весьма результативной. ${ }^{41}$

В соответствии с дефиницией Государственного департамента США, «Цифровая дипломатия» направлена на применение современных технологических инструментов, подходов, систем и информационных продуктов в миссиях и задачах дипломатии и в программах развития. Достижение этой цели основывается на «текущих усилиях использовать Facebook, Diplopedia, Twitter, LinkedIn, Communities@State и другие социальные медиа и платформы для сотрудничества и общего использования информации». ${ }^{42}$

Все это делает вопрос о контроле над сетями особенно важным. Учитывая факт, что 90 процентов физической инфраструктуры Интернета является частной собственностью и то, что действующее законодательство в этой сфере отсутствует, национальные системы безопасности сталкиваются с серьезными вызовами. ${ }^{43}$ Согласно информации Инициативы «Открытая сеть», по крайней мере сорок стран использует весьма ограничивающие фильтры и сетевые экраны для предотвращения обсуждения спорных материалов. Восемнадцать стран применяют политическую цензуру, которую инициатива определяет как «всеобъемлющую» в Китае, Вьетнаме и Иране, и как «существенную» в Ливии, Эфиопии и Саудовской Аравии. Более чем тридцать государств применяют фильтрование информации по социальным причинам, блокируя содержание по таким темам как секс, азартные

40 Смотри: Hillary Clinton's initiative “Civil Society 2.0," доступно на www.state.gov/r/pa/prs/ ps/2009/nov/131234.htm.

41 Смотри: Stefanie Babst, "Security Policies 2.0: Can Facebook, Twitter and Co. Make an Impact?," Atlantic-Community.org (6 September 2011); доступно на: http://www.atlanticcommunity.org/index/Open_Think_Tank_Article/Security_Policies_2.0\%3A_Can_Facebook $\% 2 \mathrm{C} \_$Twitter_and_Co_Make_an_Impact $\% 3 \mathrm{~F}$.

42 U.S. Department of State, "IT Strategic Plan: Fiscal Years 2011-2013 - Digital Diplomacy," 1 September 2010; доступно на: http://www.state.gov/m/irm/rls/148572.htm.

43 Tobias Franke, "Social Media: The Frontline of Cyberdefence?," NATO Review (2011); доступно на: www.nato.int/docu/review/2011/Social_Medias/cyber-defense-social-media/EN/ index.htm. 
игры и наркотики. Даже Соединенные Штаты и многие европейские страны делают это «выборочно». ${ }^{4}$

Политическая практика за последние несколько лет, связанная с контролем доступа к сетям во время кризиса, дала нам несколько уроков. Во-первых, частные Интернет компании, такие как Google, могут играть политическую роль, создавая альтернативные возможности для преодоления блокировок доступа, как то случилось в Египте. Практическая значимость этого факта заключается в том, что такие большие компании как Google, Facebook и Twitter во время кризиса могут оказаться в роли контрольно-пропускных пунктов для информации в данном сообществе. Во-вторых, к блокировке доступа легко прибегают с целью погасить волнения недемократические правительства (например, Белоруссия), но время от времени такая возможность серьезно рассматривается и демократическими правительствами (Англия). В-третьих, кризис национальной безопасности может быть как усугублен, так и разрешен, при сотрудничестве мирового сообщества через социальные сети (как в случае с Тунисом, с хакерской группой «Анонимные»).

Ясно, что кибербезопасность становится ключевым аспектом. Новая эпоха, Интернет-революции привели к беспрецедентному масштабу, скорости и доступу к информации и коммуникациям, и перераспределили основные риски и угрозы безопасности. Когда сегодня мы говорим о безопасности, мы подразумеваем кибербезопасность во всех ее аспектах - от защиты в кибервойне через защиту критической инфраструктуры от кибератак, и до защиты персональных данных, прав и свобод личности в киберпространстве.

Благодаря диффузии и атомизации власти, кибербезопасность может быть достигнута только если политика включает не-государственных акторов, если имеет место «публично-частное» общее использование информации относительно кибератак и инцидентов как в государственном управлении, так и в сфере критической инфраструктуры и ключевых ресурсов (КИКР), ${ }^{45}$ и установлено эффективное партнерство между публичным и частным сектором. Интересно упомянуть эстонский опыт Лиги для киберзащиты, которая объединяет IT профессионалов, заинтересованных в предоставлении их умений для нужд национальной безопасности. ${ }^{46}$ Соединенные Штаты, Германия и Эстония являются ведущими странами в установлении политик кибербезопасности. В будущей среде безопасности, где влияние новых технологий будет становиться все более очевидным, необходимо,

44 Как документировано Инициативой «Открытая сеть» Richard Waters and Joseph Menn, "Closing the Frontier," Financial Times (29 March 2010); цитировано в Nye, The Future of Power, 130.

45 The White House, National Security Council, "The Comprehensive National Cybersecurity Initiative,” доступно на: http://www.whitehouse.gov/cybersecurity/comprehensive-nationalcybersecurity-initiative.

46 "Ilves in Washington: All NATO Allies Must Contribute to Cyber Security," ERR News (13 April 2012); доступно на: http://news.err.ee/politics/6c3ff429-93d2-4979-81d23 de $29 \mathrm{e} 42 \mathrm{~d} 763$. 
чтобы НАТО и ЕС выработали общую эффективную стратегию кибербезопасности.

\section{Заключение}

Революция коммуникаций поставила установившуюся систему безопасности перед новыми серьезными вызовами. Как писал цитированный выше Роберт Най Младший, «Мощь всегда зависит от контекста». Эффективная и сильная политика безопасности должна быть контекстуальной и должна использовать новые возможности и инструменты коммуникационных технологий. Эти технологии не являются ни «хорошими», ни «плохими», и они сами по себе не создают больше безопасности или больше небезопасности. Инновационная и интеллигентная политика может превратить их в инструменты для укрепления политической стабильности и повышения уровня безопасности в обществе. Успешными являются те стратегии безопасности, которые отвечают на вызовы коммуникационного общества. Вызовы всегда можно рассматривать как возможности. Будут ли они реализованы, является вопросом, ответ на который нам еще предстоит узнать. 


\section{Литература}

"Germany's Pirate Party: The Ayes Have It." The Economist (2012).

Arquila, John, and David Ronfeldt. The Emergence of Noopolitik: Toward an American Information Strategy. Santa Monica, CA: RAND, 1999.

Babst, Stefanie. Security Policies 2.0: Can Facebook, Twitter and Co. Make an Impact?. Atlantic-Community.org, 2011.

Budolak, M.. "Social Media Concepts." In Petersburg School of PR: From Theory to Practice. Saint Petersburg: Roza Mira, 2009.

Buriak, Viktor. The Global Civil Society and the Network Revolutions. Simferopol, 2011.

Chun, Soon Ae, Stuart Shulman, Rodrigo Sandoval, and Eduard Hovy. "Government 2.0: Making Connections Between Citizens, Data and Government." Information Polity 15, no. $1 \& 2$ (2010): 1-9.

Faber, Peter. Power and the Westphalian System: Goodbye to All That. International Relations and Security Network Podcast, 2012.

Franke, Tobias. "Social Media: The Frontline of Cyberdefence?" NATO Review (2011).

Ghonim, Wael. Revolution 2.0: The Power of the People Is Greater than the People in Power: A Memoir. Boston: Houghton Mifflin Harcourt, 2012.

Giridharadas, Anand. "Democracy 2.0 Awaits an Upgrade." New York Times (2009).

Hardt, Michael, and Antonio Negri. "The Fight for 'Real Democracy' at the Heart of Occupy Wall Street: The Encampment in Lower Manhattan Speaks to a Failure of Representation." Foreign Affairs (2011).

Hillary Clinton's initiative “Civil Society 2.0”., 2009.

Ilves in Washington: All NATO Allies Must Contribute to Cyber Security. ERR News, 2012.

IT Strategic Plan: Fiscal Years 2011-2013 - Digital Diplomacy. U.S. Department of State, 2010.

Khatib, Lina, William H. Dutton, and Michael Thelwall. "Public Diplomacy 2.0: An Exploratory Case Study of the U.S. Digital Outreach Team." The Middle East Journal (2012).

Marsh, Sarah, and Hans-Edzard Busemann. Pirates Party's Rapid Rise Upsets German Landscape. Reuters.com, 2012. 
McLuhan, Marshall, Quentin Fiore, and Jerome Agel. The Medium is the Massage: An Inventory of Effects. New York : Bantam Books, 1967.

Merton, Robert. "The Thomas Theorem and the Matthew Effect?" Social Forces 74, no. 2 (1995): 380.

Morozov, Evgeny. "The Price of the Issue." Kommersant (2010).

Nye, Joseph S.. The Future of Power. New York: PublicAffairs, 2011.

NZ Police Let Public Write Laws. BBC News, 2007.

O'Reilly, Tim. What Is Web 2.0: Design Patterns and Business Models for the Next Generation of Software., 2005.

Prodanov, Hristo. Digital Politics . Sofia, 2011.

Pye, Lucian. "Political Communication." In The Blackwell Encyclopedia of Political Institutions. Oxford: Wiley-Blackwell, 1987.

Rheingold, Howard. Smart Mobs: The Next Social Revolution . New York: Basic Books, 2002.

Ross, Alec, and Ben Scott. "Social Media: Cause, Effect, and Response." NATO Review (2011).

Spassov, Orlin. Social Networks and Politics 2.0., 2011.

The Comprehensive National Cybersecurity Initiative. The White House, National Security Council, 2010.

Toffler, Alvin, and Heidi Toffler. Creating a New Civilization: The Politics of the Third Wave . Sofia, 1995.

Waters, Richard, and Joseph Menn. "Closing the Frontier." Financial Times (2010). 